\title{
Analisis Pengelolaan Aset Pemerintah Daerah Kabupaten Bolaang Mongondow
}

\section{FITRIA AYU LESTARI NIU ${ }^{1}$, LINTJE KALANGI ${ }^{2}$, LINDA LAMBEY ${ }^{3}$}

\author{
1,2,3 Program Magister Akuntansi, Fakultas Ekonomi dan Bisnis Universitas Sam Ratulangi \\ email: ayuniu8@gmail.com ${ }^{1}$, lintjekalangi@yahoo.com ${ }^{2}$, lindalambey@yahoo.com ${ }^{3}$
}

\begin{abstract}
This study aims to analyze the suitability of the implementation the local assets management with regulations, analyze the constraints faced in the management of local assets and efforts made for better management of regional assets. This is a qualitative study with case study approach. Data were obtained through in-depth interview technique, documentation study and observation. The result of this research shows that the local asset management in Bolaang Mongondow is implemented based on Regulation by Minister of Home Affairs No. 19 of 2016 which covers the process of planning needs and budgeting, procurement, use, utilization, security and maintenance, assessment, deletion, alienation, administration and coaching, supervision and control. But the process of destruction has not been conducted. It is because the local government has judged that there is no property belonging to the region being eligible to be destroyed. Additionally, there are obstacles encountered in asset management that are low compliance of regional apparatuses, lack of local regulations for local asset management, ineffective asset inventories, insufficient human resource competencies, lack of firm leadership commitments and resource constraints in the form of budgets and facilities in local assets management. Efforts have been conducted such as asset valuation, legal audit, asset inventory and improvement in leadership commitment. However, these efforts are required to be strongly supported by the regulation in the form of local regulations, improvement in compliance, attitude, perception, and responsibility for regional apparatus, assertiveness by the leadership, need a reward and punishment strategy for the performance of regional apparatus, involving the steward in the planning process and the use of SIMDA-BMD for the administration process in each regional work unit.
\end{abstract}

\section{Keywords: Local Asset Management, Compliance, Human Resources, Asset Inventories}

\begin{abstract}
Abstrak. Penelitian ini bertujuan untuk menganalisis kesesuaian pelaksanaan pengelolaan aset daerah dengan regulasi, menganalisis kendala yang dihadapi serta upaya yang dilakukan untuk memperbaiki pengelolaan aset daerah yang lebih baik. Penelitian ini menggunakan metode kualitatif dengan pendekatan studi kasus. Data diperoleh melalui teknik wawancara yang mendalam, studi dokumentasi dan observasi. Hasil penelitian menunjukkan bahwa pengelolaan aset daerah Kabupaten Bolaang Mongondow dilaksanakan berdasarkan Permendagri No. 19 Tahun 2016 yang meliputi proses perencanaan kebutuhan dan penganggaran, pengadaan, penggunaan, pemanfaatan, pengamanan dan pemeliharaan, penilaian, penghapusan, pemindahtanganan, penatausahaan serta pembinaan, pengawasan dan pengendalian. Namun proses pemusnahan belum dilakukan karena pemerintah daerah menilai bahwa belum ada barang milik daerah yang memenuhi syarat untuk dimusnahkan. Kendala yang ditemui dalam pengelolaan aset yaitu rendahnya kepatuhan aparatur daerah, belum adanya peraturan daerah yang mengatur proses pengelolaan aset daerah, inventarisasi aset yang belum efektif, kompetensi sumber daya manusia yang belum memadai, lemahnya komitmen pimpinan serta kurangnya sumber daya dalam bentuk anggaran dan fasilitas dalam pengelolaan aset daerah. Upaya yang dilakukan yaitu mengadakan penilaian aset, legal audit, inventarisasi aset dan perbaikan dalam komitmen pimpinan. Namun upaya ini masih perlu didukung dengan adanya regulasi dalam bentuk peraturan daerah, perbaikan dalam hal kepatuhan, sikap, persepsi, dan tanggung jawab aparatur daerah, ketegasan pimpinan, adanya strategi reward dan punishment atas kinerja aparatur daerah, melibatkan pengurus barang dalam proses perencanaan serta penggunaan SIMDA-BMD untuk proses penatausahaan pada masing-masing SKPD.
\end{abstract}

Kata Kunci: Pengelolaan Aset Daerah, Kepatuhan, Sumber Daya Manusia, Inventarisasi Aset.

\section{Pendahuluan}

Berdasarkan Standar Akuntansi Pemerintahan (2010), aset adalah sumber daya ekonomi yang dikuasai dan/atau dimiliki oleh pemerintah sebagai akibat dari peristiwa masa lalu dan dari mana manfaat ekonomi dan/atau sosial di masa depan diharapkan dapat diperoleh, baik oleh pemerintah maupun masyarakat, serta dapat diukur dalam satuan uang, termasuk sumber daya non keuangan yang diperlukan untuk penyediaan jasa bagi masyarakat umum dan sumber-sumber daya yang dipelihara karena alasan sejarah dan budaya. Aset Pemerintah Daerah merupakan salah satu unsur penting dalam penyelenggaraan pemerintahan dan pelayanan kepada masyarakat. Aset merupakan salah satu penopang perolehan pendapatan bagi Pemerintah Daerah. Oleh karena itu, Pemerintah Daerah perlu mengelola aset daerah dengan baik. Dalam pengelolaan aset daerah, pemerintah daerah harus menggunakan pertimbangan berbagai aspek mulai dari perencanaan kebutuhan, pengadaannya, penatausahaan, pemanfaatan, pemeliharaan dan pengamanan hingga pengawasannya agar aset daerah 
mampu memberikan kontribusi optimal bagi pemerintah daerah yang bersangkutan. Pemerintah mengeluarkan Peraturan Menteri Dalam Negeri Nomor 17 Tahun 2007 yang kemudian direvisi menjadi Permendagri No. 19 Tahun 2016 tentang pengelolaan barang milik daerah sebagai pedoman teknis dan administrasi dalam pengelolaan barang milik daerah.

Dalam Peraturan Peraturan Menteri Dalam Negeri Nomor 19 Tahun 2016 tentang pengelolaan barang milik daerah, ruang lingkup pengelolaan barang milik daerah ini meliputi 11 tahapan dalam siklus pengelolaan aset daerah yakni (1) perencanaan kebutuhan dan penganggaran; (2) pengadaan; (3) penggunaan; (4) pemanfaatan; (5) pengamanan dan pemeliharaan; (6) penilaian; (7) pemindahtanganan; (8) pemusnahan; (9) penghapusan; (10) penatausahaan; (11) pembinaan, pengawasan dan pengendalian. Siklus pengelolaan aset adalah tahapan - tahapan yang harus dilalui dalam manajemen aset. Dengan kata lain aset daerah adalah urusan yang harus dikelola dengan baik dan benar sehingga akan terwujud pengelolaan aset daerah yang transparan, efisien, bertanggung jawab, dan adanya kepastian nilai aset daerah yang dapat berfungsi untuk menunjang pelaksanaan tugas dan kewenangan Pemerintah Daerah (Yusuf, 2010:33).

Berbagai studi membuktikan bahwa tidak banyak perhatian serius yang diberikan pada pengelolaan aset daerah jika dibandingkan dengan pengelolaan keuangan daerah. Padahal aset daerah sama pentingnya dengan pengelolaan keuangan daerah. Syamsuddin (2016) menyatakan bahwa banyak Instansi Pemerintah masih menganggap bahwa pengelolaan aset secara fisik hanyalah sekedar instrumen pengelolaan daftar aset. Realita di lapangan menunjukkan banyak kasus yang sebenarnya dimulai dari salah kelola dan salah urus masalah aset, sehingga berdampak kerugian yang tidak sedikit dan di pemerintahan sendiri sangat berpengaruh terhadap opini laporan keuangan yang menjadi salah satu bentuk penilaian atas akuntabilitas pengelolaan keuangan daerah. Pengelolaan aset daerah sebenarnya merupakan bagian yang tidak terpisahkan dari pengelolaan keuangan daerah dan secara umum terkait dengan adiministrasi pembangunan daerah khususnya yang berkaitan dengan nilai aset, pemanfaatan aset, pencatatan nilai aset dalam neraca, maupun dalam penyusunan prioritas dalam pembangunan.

Dalam berbagai temuan audit, salah satu penyebab opini Wajar Tanpa Pengecualian (WTP) oleh BPK tidak dapat diperoleh Pemerintah Daerah terhadap hasil pemeriksaan laporan keuangannya dikarenakan masalah pengelolaan aset. Permasalahan yang menyebabkan pengecualian atas laporan keuangan tersebut adalah pencatatan aset tetap yang belum sepenuhnya didukung oleh bukti kepemilikan serta pencatatan aset yang belum sesuai dengan Standar yang berlaku. Berbagai permasalahan dalam pengelolaan aset daerah membutuhkan keseriusan Pemerintah Daerah untuk menata pengelolaannya, mulai dari perencanaan hingga pemanfaatan dan pengawasannya. Setidaknya tata kelola tersebut dapat meminimalkan berbagai penyimpangan yang ada, termasuk temuan BPK dalam pemeriksaan laporan keuangan setiap tahun anggaran. Sutaryo (2010) menyatakan bahwa pengelolaan aset daerah bukanlah pekerjaan yang mudah. Hal ini terbukti dari masih banyaknya pengecualian kewajaran atas nilai aset pemerintah daerah dalam opini BPK atas laporan keuangan pemerintah daerah.

BPK Sulut (2016) dalam siaran pers BPK Perwakilan Sulut menyebutkan bahwa permasalahan lemahnya pengendalian atas pengelolaan aset tetap pada Pemerintah Daerah Kabupaten Bolaang Mongondow Tahun Anggaran 2015 yaitu pertama, pencatatan aset tetap berupa tanah yang tidak dilaksanakan oleh Pemerintah Daerah Kabupaten Bolaang Mongondow dikarenakan tanah tersebut tidak dapat ditelusuri letaknya dan tidak dapat dijelaskan dasar pencatatannya dikarenakan tidak ada bukti kepemilikan/ dokumentasi berupa surat keterangan hibah. Kedua, aset tetap berupa peralatan dan mesin, gedung dan bangunan serta jalan, irigasi dan jaringan dicatat secara gabungan dan tidak dapat diketahui dasar pencatatannya dikarenakan tidak adanya bukti kepemilikan dan belum pernah dilakukan penilaian dalam rangka penyusunan LKPD. Ketiga, kapitalisasi atas kegiatan rehabilitasi yang dicatat sebagai aset tetap terpisah dari induknya, sehingga berdampak ke perhitungan akumulasi penyusutan yang disebabkan oleh tidak adanya dasar pencatatan akuntansi berupa hasil penilaian atas aset tetap serta kurangnya pemahaman dari pengelola atau pengurus barang mengenai kapitalisasi aset tetap.

Pada Tahun 2017, BPK Perwakilan Sulut menyampaikan hasil pemeriksaan atas Laporan Keuangan Pemerintah Daerah Kabupaten Bolaang Mongondow untuk tahun anggaran 2016 meraih opini Disclaimer (Tidak Memberikan Pendapat). Penyebab diraihnya opini tersebut yaitu karena temuan audit yang tidak ditindaklanjuti, sehingga temuan pada tahun anggaran 2016 meliputi temuan yang berulang pada tahun anggaran sebelumnya seperti lemahnya pengendalian atas pengelolaan aset daerah, masih banyak aset daerah yang fisiknya ada namun tidak tercatat dalam KIB dan neraca, tidak 
pernah dilakukannya sensus barang atau inventarisasi aset, kapitalisasi yang mengakibatkan pemerintah Kabupaten Boloaang Mongondow tidak bisa menentukan akumulasi penyusutan dikarenakan tidak adanya penilaian aset dalam rangka penyusunan LKPD, bahkan masih ada aset yang bernilai 1, belum ada dasar pencatatan aset tanah sebab tidak ada bukti kepemilikan/ bukti dokumentasi, kendaraan yang belum bisa ditelusuri keberadaannya serta pencatatan secara terpisah untuk tanah di bawah badan jalan yang menjadi temuan di Dinas Pekerjaan Umum namun belum dilakukan dikarenakan belum adanya penilaian atas tanah tersebut.

Berdasarkan hasil pemeriksaan atas laporan keuangan Pemerintah Kabupaten Bolaang Mongondow yang masih belum meraih opini Wajar Tanpa Pengecualian salah satunya diakibatkan oleh pengelolaan aset dan didukung dengan data dari Laporan Hasil Pemeriksaan oleh BPK, maka penelitian ini bertujuan untuk memperoleh gambaran yang jelas tentang pengelolaan aset daerah Kabupaten Bolaang Mongondow dilihat dari kesesuaiannya dengan peraturan yang berlaku, dan menganalisis kendala-kendala yang dihadapi beserta upaya-upaya yang harus dilakukan untuk mengatasi kendala-kendala dalam pengelolaan aset daerah yang lebih baik.

Tujuan penelitian ini untuk: 1) menganalisis kesesuaian pelaksanaan pengelolaan aset daerah dengan regulasi yang ditetapkan Pemerintah; 2) menganalisis kendala yang dihadapi dalam pengelolaan aset daerah; 3) menganalisis upaya memperbaiki pengelolaan aset daerah agar lebih baik di Kabupaten Bolaang Mongondow.

\section{Model Analisis}

Model analisis pada penelitian ini dimulai dengan melihat fenomena yang terjadi pada pengelolaan aset daerah dan menentukan topik penelitian. Selanjutnya melakukan pengumpulan data dengan teknik wawancara dan didukung dengan studi dokumentasi dan observasi. Langkah berikutnya yaitu mengolah data, menguji keabsahan data dan menyusun laporan hasil penelitian.

Gambar 1. Model Analisis

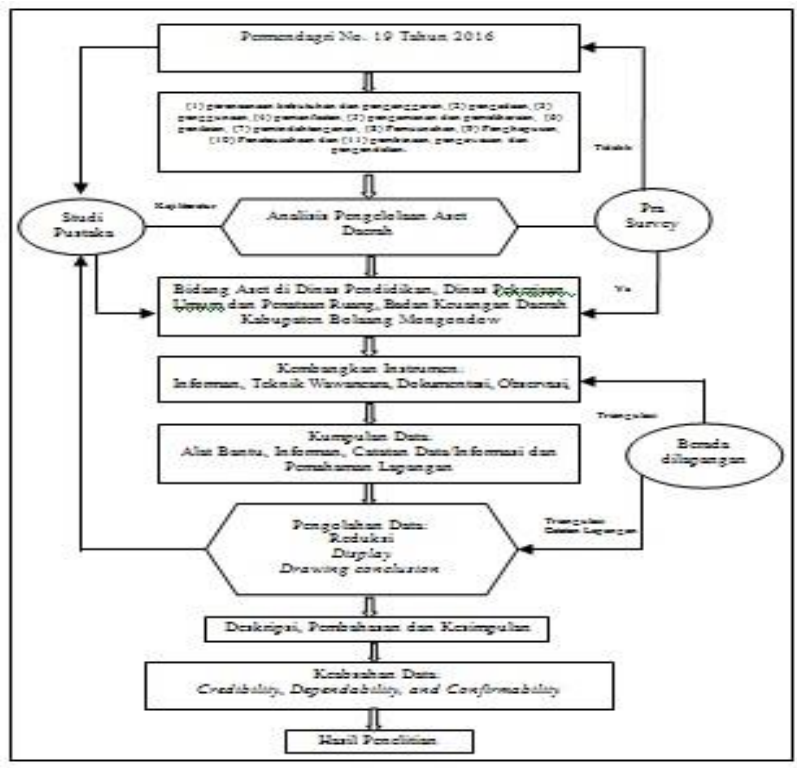

\section{Metode Penelitian}

Penelitian ini menggunakan metode pendekatan kualitatif untuk mengeksplorasi dan memahami makna yang oleh sejumlah individu atau sekelompok orang dianggap berasal dari masalah sosial atau kemanusiaan (Creswell, 2010). Penelitian ini menggunakan pendekatan metode studi kasus yang menurut Creswell (2010) merupakan strategi penelitian dimana didalamnya peneliti menyelidiki secara cermat suatu program, peristiwa, aktivitas, proses, atau sekelompok individu. Endraswara (2013:78) menyatakan bahwa studi kasus dibagi menjadi dua golongan, yaitu studi kasus berupa penyimpangan dari kewajaran dan studi kasus ke arah perkembangan yang positif. Penelitian ini termasuk dalam golongan studi kasus yang berupa penyimpangan dari kewajaran karena pelaksanaan pengelolaan aset daerah yang dinilai bermasalah oleh BPK, sehingga masih menjadi salah satu temuan dalam pemeriksaan laporan keuangan pemerintah daerah. Lewat studi kasus, maka kendala-kendala yang menghambat pengelolaan aset daerah akan terangkat ke permukaan hingga akhirnya menjadi 
pengetahuan publik, serta berusaha menemukan tindak lanjut berupa upaya perbaikan yang perlu dilakukan untuk mengatasi kendala yang dihadapi dalam pengelolaan aset daerah.

Teknik pengumpulan data yang dilakukan dalam penelitian ini adalah wawancara, studi dokumentasi dan observasi atau gabungan ketiganya yang disebut triangulasi. Informan kunci ditetapkan secara purposive sampling dengan syarat memenuhi kriteria yang ditetapkan untuk mendapatkan informasi yang tepat dan akurat. Teknik analisis data yang digunakan dalam penelitian ini adalah teknik analisis Model Milles dan Huberman dalam Sugiyono (2015:85) yang terdiri atas data reduction, data display dan drawing conclusion/verification yang dilakukan secara interaktif dan berlangsung secara terus menerus sampai tuntas, sehingga datanya mencapai jenuh. Uji keabsahan data yang diguunakan dalam penelitian ini meliputi uji validitas internal (credibility) dengan memanfaatkan triangulasi yang terdiri dari triangulasi sumber dan triangulasi teknik, uji reliabilitas (dependability) yang dilakukan oleh pembimbing mulai dari memeriksa keseluruhan aktifitas penelitian, mulai dari menentukan masalah/ fokus, menentukan sumber data, menentukan analisis data, melakukan uji keabsahan data dan sampai pada pembuatan kesimpulan/ laporan akhir serta uji objektivitas (confirmability) yang menguji hasil penelitian, dikaitkan dengan proses yang dilakukan.

\section{Analisis dan Pembahasan}

Penelitian dilakukan selama 3 (tiga) bulan sejak bulan Juli sampai September 2017 dengan melakukan wawancara sesuai dengan pedoman wawancara kepada informan dengan menggunakan alat perekam untuk merekam seluruh isi wawancara, serta menggunakan instrumen pendukung antara lain buku catatan, alat perekam berupa audio, kamera untuk mendokumentasikan kegiatan di lapangan dan laptop untuk mengetik hasil penelitian dan rekaman wawancara sehingga berbentuk transkrip wawancara.

\section{Kesesuaian Pelaksanaan Siklus/Proses Pengelolaan Barang Milik Daerah dengan Regulasi yang Ditetapkan Pemerintah}

Pedoman pengelolaan barang milik daerah yang digunakan oleh Pemerintah Daerah Kabupaten Bolaang Mongondow yaitu Permendagri No. 19 Tahun 2016. Belum adanya turunan dari Permendagri No. 19 Tahun 2016 dalam bentuk Peraturan Daerah mengakibatkan pengelolaan aset daerah mengacu langsung pada Permendagri No. 19 Tahun 2016. Pengelolaan barang milik daerah di Kabupaten Bolaang Mongondow berdasarkan Permendagri No. 19 Tahun 2016 hanya meliputi sepuluh dari sebelas proses yang ada yaitu perencanaan kebutuhan dan penganggaran, pengadaan, penggunaan, pemanfaatan, pengamanan dan pemeliharaan, penilaian, penghapusan, pemindahtanganan, penatausahaan serta pembinaan, pengawasan dan pengendalian. Salah satu proses yang belum dilaksanakan yaitu proses pemusnahan yang dinilai pemerintah daerah bahwa belum ada barang milik daerah yang memenuhi syarat untuk dimusnahkan.

1. Perencanaan kebutuhan dan penganggaran barang milik daerah di Kabupaten Bolaang Mongondow secara keseluruhan, masih banyak SKPD yang tidak menyampaikan Rencana Kebutuhan Barang Milik Daerah (RKBMD) dan Rencana Kebutuhan Pemeliharan Barang Milik Daerah (RKPBMD) yang disebabkan rendahnya tingkat kepatuhan dari masing-masing SKPD.

2. Pengadaan barang milik daerah di Kabupaten Bolaang Mongondow dilaksanakan oleh panitia pengadaan di tiap-tiap SKPD atau SKPD melalui ULP (Unit Layanan Pengadaan) sesuai ketentuan yang disebutkan dalam Peraturan Presiden Nomor 54 Tahun 2010 tentang pengadaan barang/jasa pemerintah. Panitia pengadaan ditetapkan dengan Surat Keputusan Bupati dengan mengikuti mekanisme yang ditetapkan dalam aturan pengadaan.

3. Penggunaan barang milik daerah di Kabupaten Bolaang Mongondow belum terlaksana secara optimal. Hal ini dikarenakan sebagian besar SKPD belum patuh dan sadar dalam melaksanakan proses penggunaan yang tepat sesuai dengan Permendagri No. 19 Tahun 2016 sehingga hanya sebagian kecil SKPD yang melaksanakan proses penggunaan seperti menetapkan status pengguna barang, membuat berita acara serah terima dalam rangka pemindahan status pengguna barang atau pengembalian barang sesuai dengan ketentuan perundang-undangan.

4. Pemanfaatan aset daerah telah dilaksanakan namun hanya pada sebagian bentuk pemanfaatan yang dilaksanakan yaitu pinjam pakai dan sewa yang menjadi temuan BPK. Temuan atas pemanfaatan dalam bentuk sewa disebabkan oleh adanya kendala regulasi yang masih dalam proses penyusunan serta keandalan atau validasi data aset daerah yang dimiliki.

5. Pengamanan dan pemeliharaan barang milik daerah di Kabupaten Bolaang Mongondow belum maksimal karena terdapat beberapa kendala seperti kendaraan dinas yang masih berada di pejabat 
yang pindah SKPD atau daerah dan aset kantor lainnya yang hilang atau tidak diketahui keberadaannya. Selain itu, masih banyak tanah yang belum memiliki bukti kepemilikan, masih membutuhkan peraturan daerah tentang pengamanan dan pemeliharaan aset daerah serta dukungan fasilitas berupa gudang bagi tiap-tiap SKPD sebagai bentuk pengamanan fisik pada aset yang dimiliki.

6. Penilaian aset di Kabupaten Bolaang Mongondow belum pernah dilaksanakan baik dalam rangka penyusunan neraca pemerintah daerah, pemindahtanganan dan pemanfaatan. Hal ini disebabkan oleh keakuratan dan keandalan data aset yang masih diragukan, banyaknya aset yang belum dapat terdeteksi atau masih berada di pejabat yang telah pensiun atau pindah tugas ke daerah pemekaran serta bukti kepemilikan yang belum dimiliki oleh pemerintah daerah. Proses penilaian yang sedang dilakukan di Kabupaten Bolaang Mongondow yaitu dalam rangka pemanfaatan, pemindahtanganan dan pengamanan dengan melakukan sensus barang (inventarisasi) baik itu berupa tanah, gedung/bangunan, kendaraan dinas serta peralatan dan mesin yang belum diketahui keberadaan juga dasar pencatatannya (bukti kepemilikan). Dalam hal penilaian Pemerintah Kabupaten Bolaang Mongondow bekerja sama dengan KPKNL Manado selaku pihak yang berkompeten dalam hal penilaian barang milik daerah.

7. Pemindahtanganan aset di Kabupaten Bolaang Mongondow telah dilakukan sesuai dengan Permendagri No. 19 Tahun 2016, namun belum sepenuhnya terlaksana dengan baik. Bentukbentuk pemindahtanganan yang telah dilakukan seperti hibah dan penjualan/lelang. Kendala yang muncul dalam proses pemindahtanganan yaitu pada proses hibah yang masih belum didasari oleh regulasi yang secara khusus dibuat oleh pemerintah daerah. Selain itu, pemindahtanganan aset ke daerah pemekaran terkendala oleh adanya sengketa kepemilikan tanah dengan masyarakat setempat serta dokumentasi pada saat pemindahtanganan aset daerah dalam bentuk hibah yang tidak disertai dengan berita acara serah terima.

8. Penghapusan aset di Kabupaten Bolaang Mongondow dilaksanakan apabila barang sudah tidak dikuasai oleh pengguna dan pengelola barang dalam artian barang-barang tersebut sudah terlelang atau terjual dan telah dihibahkan ke pihak atau daerah lain yang telah dilaksanakan secara bertahap dari tahun 2011. Penghapusan aset di Kabupaten Bolaang Mongondow sudah sesuai aturan permendagri No. 19 Tahun 2016, namun secara keseluruhan proses penghapusan ini belum dilaksanakan secara optimal dikarenakan masih terkendala dengan adanya reklasifikasi aset tetap karena barang hilang atau rusak yang belum bisa dilakukan penghapusan.

9. Penatausahaan barang milik daerah di Kabupaten Bolaang Mongondow belum dilaksanakan dengan baik sesuai dengan Permendagri No. 19 Tahun 2016. Hal tersebut dikarenakan masih banyaknya kendala-kendala yang ditemui dalam proses penatausahaan seperti dari aspek fisik, aspek yuridis, kepatuhan dari SKPD untuk membuat pembukuan, inventarisasi dan pelaporan seperti masih banyaknya barang yang tidak tercatat secara jelas dan rinci dalam kartu inventarisasi barang (KIB).

10. Pembinaan, pengawasan dan pengendalian di Kabupaten Bolaang Mongondow telah dilaksanakan sesuai dengan Permendagri No. 19 Tahun 2016, tetapi masih ada temuan dari hasil pemeriksaan BPK yang menyatakan bahwa masih lemahnya pengendalian aset yang disebabkan oleh kepatuhan, sikap dan persepsi pengguna dan pengurus barang di tiap-tiap SKPD. Pembinaan yang tidak menghasilkan dampak positif diakibatkan peserta bimtek tidak serius dan bertanggung jawab mengikuti bimtek tersebut.

\section{Kendala Yang Dihadapi Dalam Pengelolaan Aset Daerah Kabupaten Bolaang Mongondow}

Ada 6 (enam) kendala yang ditemui dalam pengelolaan barang milik daerah yaitu: 1) rendahnya kepatuhan aparatur daerah; 2) belum adanya peraturan daerah yang mengatur secara rinci proses pengelolaan aset daerah sebagai turunan dari Permendagri No. 19 Tahun 2016; 3) inventarisasi aset yang belum efektif dan optimal; 4) kompetensi sumber daya manusia yang belum mendukung pengelolaan aset daerah; 5) komitmen pimpinan yang kurang tegas dan belum maksimal serta 6) kendala pada sumber daya dalam bentuk anggaran dan fasilitas pengelolaan aset daerah.

Kendala pertama yaitu kepatuhan yang ditemukan dalam proses perencanaan kebutuhan dan penganggaran, penggunaan, pengamanan dan pemeliharaan, penatausahaan serta pembinaan, pengawasan dan pengendalian. Kendala kepatuhan yang terjadi dalam proses perencanaan kebutuhan dan penganggaran ditemukan bahwa masih banyak SKPD yang tidak patuh dalam membuat dan menyerahkan daftar Rencana Kebutuhan Barang Milik Daerah (RKBMD) dan daftar Rencana Kebutuhan Pemeliharaan Barang Milik Daerah (RKPBMD) kepada Badan Keuangan Daerah selaku 
SKPKD. Proses penggunaan belum sesuai dengan Permendagri No. 19 Tahun 2016, dikarenakan dalam penetapan status pengguna maupun pengurus barang tidak disertai dengan SK dari Bupati, hanya berdasarkan SK Kepala SKPD.

Kendala kepatuhan dalam proses pengamanan dan pemeliharaan disebabkan tidak adanya penetapan status pengguna barang dalam proses penggunaan yang sesuai dengan Permendagri No. 19 Tahun 2016. Sehingga proses pengamanan barang yang tidak diketahui siapa pengguna barang yang disebabkan kelalaian SKPD dalam membuat berita acara dalam rangka serah terima pengguna barang dengan pengurus barang. Proses penatausahaan yang baik belum terjadi dikarenakan adanya kendala ketidakpatuhan oleh SKPD dalam mencatat dan melaporkan KIB masih secara "gelondongan" artinya tidak secara rinci memenuhi spesifikasi mulai dari jenis, volume hingga harga per satuan barang yang ada di SKPD serta pelaporan tiap SKPD hanya dilakukan oleh sebagian kecil SKPD. Ketidakpatuhan dalam proses pembinaan, pengawasan dan pengendalian khususnya dalam proses pembinaan masih belum terlaksana secara efektif dikarenakan pengurus barang yang dilibatkan dalam pelatihan pengelolaan aset daerah tidak mengikuti bimbingan teknis dengan baik, namun sebaliknya kegiatan bimtek hanya dihadiri untuk formalitas saja dan untuk memenuhi kewajiban absensi.

Perspektif pertama dalam memahami keberhasilan suatu implementasi adalah kepatuhan para implementor dalam melaksanakan regulasi yang tertuang dalam dokumen regulasi (Purwanto dan Sulistyastuti, 2012:69). Implementasi kebijakan pada prinsipnya merupakan cara agar sebuah kebijakan dapat mencapai tujuannya. Lester dan Stewart yang dikutip oleh Winarno, menjelaskan bahwa implementasi kebijakan dipandang dalam pengertian luas merupakan alat administrasi hukum dimana berbagai aktor, organisasi, prosedur dan teknik yang bekerja bersama-sama untuk menjalankan kebijakan guna meraih dampak atau tujuan yang diinginkan. (Lester dan Stewart dalam Winarno, 2002:101). Kepatuhan pada regulasi dalam pengelolaan barang milik daerah merupakan pelaksanaan dari azas kepastian hukum, yaitu pengelolaan barang milik daerah harus dilaksanakan berdasarkan hukum dan peraturan perundang-undangan. Agar implementasi suatu kebijakan pengelolaan barang milik daerah berhasil secara efektif dan efisien, para pelaksana (implementers) harus mengetahui apa yang harus dilakukan dan mempunyai kemampuan untuk melakukan kebijakan itu, serta mempunyai kemauan untuk melaksanakan kebijakan tersebut (Inayah, 2010).

Kendala kedua yaitu regulasi yang ditemukan dalam proses perencanaan kebutuhan dan penganggaran, pemanfaatan, serta pengamanan dan pemeliharaan. Proses perencanaan kebutuhan dan penganggaran hanya dilaksanakan sesuai dengan Permendagri No. 19 Tahun 2016. Hal ini disebabkan belum tersedianya peraturan daerah yang mengatur lebih rinci tentang teknis dan mekanisme perencanaan kebutuhan dan penganggaran barang milik daerah, sehingga pelaksanaan perencanaan tidak terarah dan terkoordinasi dengan baik sesuai dengan kondisi pada masing-masing SKPD. Proses pemanfaatan belum dilaksanakan secara optimal karena terkendala regulasi yang mengatur mekanisme bentuk-bentuk pemanfaatan aset yang dimiliki daerah. Tidak adanya regulasi dalam bentuk peraturan daerah dan peraturan bupati mengakibatkan proses pemanfaatan aset tidak jelas, bahkan belum dapat dilaksanakan dalam sebagian besar bentuk pemanfaatan karena regulasi yang menjelaskan tata cara dan mekanisme hingga perhitungan waktu dan keuntungan bagi pemerintah daerah yang belum tersedia. Kendala regulasi yang belum tersedia dalam bentuk peraturan daerah menyulitkan aparatur daerah yang bertugas untuk mengelola dan bertanggung jawab atas keamanan barang milik daerah dalam proses pengamanan dan pemeliharaan.

Peraturan Daerah adalah peraturan yang ditetapkan kepala daerah atas persetujuan Dewan Perwakilan Rakyat Daerah (DPRD) dalam rangka menyelenggarakan otonomi daerah. Peraturan Daerah dibuat berdasarkan Undang-Undang atau penjabaran lebih lanjut dari peraturan perundangundangan yang lebih tinggi. Untuk melaksanakan Peraturan Daerah dan atas kuasa peraturan perundang-undangan lain yang berlaku, kepala daerah menetapkan keputusan kepala daerah (Wirjosoegito, 2004:14). Landasan yang digunakan dalam menyusun Perundang-Undangan yang tangguh dan berkualitas menurut Tjandra dan Harsono (2009:25) yang berkaitan dengan pengelolaan aset daerah yang terkendala regulasi yaitu landasan yuridis. Landasan yuridis yakni ketentuan hukum yang menjadi dasar kewenangan (bevoegheid competentie) pembuat Peraturan Perundang-Undangan agar dapat menata dan mengatur Standar Operasional Pelaksanaan Pengelolaan Aset daerah yang secara rinci dan sesuai dengan keadaan dan kondisi daerahnya.

Kendala yang ketiga yaitu inventarisasi aset yang ditemukan dalam proses perencanaan kebutuhan dan penganggaran, pemanfaatan dan penatausahaan. Proses perencanaan kebutuhan khususnya dalam perencanaan kebutuhan pemeliharaan barang milik daerah belum dicatat dan dilaporkan secara rinci oleh masing-masing SKPD kepada SKPKD. Sedangkan pada proses 
pemanfaatan masih banyak aset yang bisa dimanfaatkan namun tidak diakui dan dicatat dalam neraca daerah dan Kartu Invetaris Barang, sehingga pemanfaatan tidak bisa dilakukan karena aset yang berpotensi untuk di sewakan atau dipinjampakaikan tidak didasari dengan inventarisasi yang akurat dan handal. Proses lain yang paling banyak mengalami kendala dalam pencatatan yaitu proses penatausahaan seperti salah catat dalam penggolongan aset tetap, tidak dilaksanakan pencatatan atau pemindahan saldo aset yang telah dipindahtangankan atau telah dihapuskan serta tidak adanya rincian barang sehingga hal tersebut dianggap "gelondongan" atau tidak diketahui secara jelas dan rinci penggolongan dan kodefikasi barang.

Untuk proses penatausahaan, ketiadaan bukti kepemilikan ini menjadi penghambat dalam hal pengakuan aset yang menjadi tidak andal sebagaimana yang dijelaskan dalam PSAP No. 7 tentang akuntansi aset tetap yang menyatakan bahwa keandalan pengakuan suatu aset akan lebih andal apabila disertai dengan bukti kepemilikan tersebut. Prinsip Keandalan merupakan catatan atau laporan akuntansi yang didasarkan atas data/informasi yang tersedia yang paling dapat diandalkan (data yang dapat dibuktikan/ditelusuri kebenarannya), sehingga catatan dan laporan tersebut akan menjadi akurat dan berguna. Di dalam akuntansi, prinsip keandalan muncul saat penilaian harga dapat di lakukan oleh orang-orang yang profesional di bidangnya secara independen dan objektif.

Kendala keempat yaitu kompetensi sumber daya manusia yang ditemukan dalam proses perencanaan kebutuhan dan penganggaran, penggunaan, pemanfaatan serta pembinaan, pengawasan dan pengendalian. Kendala yang ditemui dalam proses perencanaan kebutuhan dan penganggaran adalah pemahaman sumber daya manusia dalam hal ini aparatur daerah selaku pelaksana pengelolaan aset daerah yang masih belum memadai. Pemahaman atas biaya pemeliharaan dan proses pengadaan yang sesuai dengan regulasi yang ditetapkan tidak sejalan dengan pemahaman yang dimiliki oleh aparatur daerah sehingga hal ini menghambat pengelolaan aset daerah. Dalam proses penggunaan, kurangnya kompetensi sumber daya manusia yang dimiliki oleh aparatur daerah dalam mengemban tugas sebagai pengurus barang membuat proses penunjukkan pengurus barang di SKPD, kepala SKPD hanya menunjuk orang yang bersedia menjadi pengurus barang tanpa melihat kriteria yang seharusnya dipenuhi oleh pengurus barang tersebut.

Kendala kelima yaitu kesadaran dari aparatur daerah dalam hal penggunaan aset daerah yang tidak mengembalikan barang pada pengurus barang pada saat aparatur tersebut pindah ke SKPD lain maupun ke daerah tugas yang baru. Proses pemanfaatan aset yang terjadi di lapangan belum efektif dikarenakan persepsi aparatur daerah di SKPD tertentu yang masih terdapat ego sektoral yang memanfaatkan aset seperti pada lahan yang dimiliki Bolaang Mongondow untuk dijadikan lahan percontohan, namun karena persepsi aparatur maka muncul ego sektoral untuk memanfaatkan lahan tersebut tidak secara efektif dan efisien. Kendala kompetensi sumber daya manusia yang paling banyak ditemui yaitu dalam proses pembinaan, pengawasan dan pengendalian. Hal tersebut terjadi karena adanya sikap dan persepsi dari aparatur daerah yang mengakibatkan timbul kendala lain yaitu kepatuhan. Akibat sikap dan persepsi dari aparatur daerah yang menganggap pengelolaan aset sebagai hal yang tidak memiliki pengaruh penting dibandingkan pengelolaan keuangan daerah, maka aparatur menjadi tidak patuh terhadap regulasi yang ditetapkan. Dalam proses pembinaan, sikap aparatur daerah yang menjadi pengurus dan pengguna barang mengikuti kegiatan bimtek tidak secara sungguhsungguh dan bertanggung jawab. Begitu pun dalam proses pengawasan, kendala persepsi aparatur daerah sebagai pengguna barang yang menganggap barang yang dikuasainya sudah menjadi barang miliknya, sehingga pada saat pengguna barang ditugaskan ke tempat yang baru, pengguna barang tersebut membawa barang yang dikuasainya dan tidak mengembalikannya pada pengurus barang.

Menurut Munaim (2012), diperlukan pemahaman dan kesamaan persepsi dan langkah secara integral dan menyeluruh dari semua SKPD dalam menjamin terlaksananya pengelolaan barang milik daerah. Hutapea dan Thoha (2008:8) mengungkapkan bahwa ada tiga komponen utama pembentukan kompetensi, yang menjadi kendala kompetensi SDM dalam pengelolaan aset Kabupaten Bolaang Mongondow yaitu pengetahuan (knowledge), keterampilan (skill) dan sikap (attitude). Suharto (2012) menyatakan bahwa kualitas sumber daya manusia merupakan kemampuan dari pegawai dalam menjalankan proses pengelolaan yang dilihat dari kemahiran seseorang, latarbelakang pendidikan, persyaratan yang harus diikuti untuk dapat menjalankan proses pengelolaan, pelatihan-pelatihan, masalah professional dan sosialisassi peraturan yang mengalami perubahan. Kunci keberhasilan pengelolaan barang milik daerah adalah harus tersedianya pegawai yang kompeten dalam bidang pengelolaan barang milik daerah. Untuk mendapatkan pegawai yang kompeten maka diperlukan adanya suatu standar yaitu pegawai yang memiliki pengetahuan tentang aset daerah, yang mempunyai 
keterampilan tentang pengelolaan aset daerah, dan pegawai yang mempunyai sikap terhadap pengelolaan aset daerah (Yusuf, 2010: 47).

Kendala keenam yaitu komitmen pimpinan yang ditemukan dalam proses perencanaan kebutuhan dan penganggaran, penggunaan, penghapusan dan penatausahaan. Pada saat kepemimpinan yang lama, lemahnya komitmen organisasi dan pimpinan berupa ketegasan dalam pelaksanaan pengelolaan aset, menjadi kendala serta berpengaruh terhadap jalannya pengelolaan aset daerah yang baik. Tidak adanya sistem pemberian penghargaan maupun sanksi bagi SKPD maupun pengurus barang yang patuh ataupun lalai dalam melaksanakan proses pengelolaan aset yang sesuai dengan regulasi yang ditetapkan oleh Pemerintah. Kendala komitmen pimpinan berupa tidak adanya kesesuaian antara perilaku pimpinan dengan regulasi yang menyatakan bahwa dalam proses penggunaan harus ditetapkan dengan adanya SK dari bupati yang dilaksanakan berdasarkan usulan dari Kepala Dinas melalui Sekertaris Daerah. Ketetapan dalam bentuk SK Bupati ini mengatur tentang penunjukkan pengurus barang untuk tiap-tiap SKPD. Namun hal tersebut tidak terjadi di setiap SKPD, para pengurus barang hanya memiliki dasar penunjukkan sebagai pengurus barang dari Kepala SKPD tanpa adanya SK resmi dari Bupati.

Komitmen pimpinan yang menjadi kendala dalam proses penghapusan barang di Kabupaten Bolaang Mongondow terjadi pada saat Badan Keuangan Daerah selaku SKPKD secara kolektif mengusulkan untuk melakukan proses penghapusan atas aset dan telah menyerahkan usulan tersebut dalam bentuk SK penghapusan ke pihak pimpinan daerah. Namun karena kendala komitmen pimpinan yang kurang baik, hingga saat ini SK Penghapusan tersebut tidak ada tindak lanjutnya. Sehingga hal ini mengakibatkan saldo aset yang masuk dalam SK Pengusulan Penghapusan masih terus tercatat dalam neraca LKPD. Kurangnya pemahaman dan ketegasan dari pimpinan membuat proses penatausahaan aset daerah menjadi tidak baik dan tidak optimal serta membuat para pelaksana di masing-masing SKPD lalai dan tidak berupaya semaksimal mungkin dalam mengelola aset dengan baik dan bertanggungjawab.

Tanpa adanya komitmen dari pimpinan untuk menerapkan peraturan tersebut maka peraturan tersebut tidak akan berhasil dalam penerapannya. Oleh karena itu, kepatuhan pada regulasi yang dilakukan oleh para pelaksana pengelola barang milik daerah membutuhkan komitmen pimpinan. Komitmen pimpinan juga dibutuhkan dalam pelaksanaan komunikasi pada suatu organisasi. Menurut Simamora (2012), komitmen pimpinan diperlukan dalam mengatasi permasalahan yang menyangkut pengelolaan barang milik daerah. Komitmen Kepala SKPD dibutuhkan dalam hal tidak sering melakukan pergantian personal pengurus dan penyimpan barang. Pengurus dan penyimpan barang harus bekerja satu tahun anggaran sesuai dengan surat keputusan pengangkatan. Jika pergantian petugas pengelola barang diperlukan harus ada kaderisasi terlebih dahulu terhadap penggantinya. Selain itu, kepala SKPD memberikan perhatian serius bagi aset yang dikelolanya secara professional dengan tidak menomorduakan urusan pengelolaan barang milik daerah, karena posisi kepala SKPD selain sebagai pengguna anggaran juga sebagai pengguna barang yang bertanggungjawab terhadap barang milik daerah yang dikelolanya.

Kendala yang terakhir adalah sumber daya dalam bentuk anggaran dan fasilitas yang ditemukan dalam proses pengamanan dan pemeliharaan serta pembinaan, pengawasan dan pengendalian. Proses pengamanan dan pemeliharaan tidak dapat dilakukan secara maksimal karena terhambat anggaran yang tidak dapat memenuhi pemeliharaan aset-aset seperti di Dinas PU masih sangat membutuhkan anggaran untuk memelihara aset seperti eskafator yang jika dipelihara bisa menambah pendapatan asli daerah. Kendala anggaran juga menjadi kendala dalam proses inventarisasi aset di Dinas Pendidikan dan berpengaruh pada insentif yang diterima oleh pengurus barang yang tidak sesuai dengan beban kerja yang harus dilakukan. Selain itu tidak adanya gudang menyulitkan pengurus barang untuk menyimpan dan mengamankan barang baik yang masih dalam kondisi baik maupun yang sudah dalam kondisi rusak.

Sumber daya anggaran merupakan sumber daya yang mempengaruhi implementasi setelah adanya sumber daya menusia, terbatasnya anggaran yang tersedia menyebabkan kualitas pelayanan terhadap publik yang harus diberikan kepada masyarakat juga terbatas. Terbatasnya anggaran menyebabkan disposisi para pelaku rendah bahkan akan terjadi goal displacement yang dilakukan oleh pelaku terhadap pencapaian tujuan dan sasaran yang telah ditetapkan (Edward III, 1980). Sumber daya peralatan juga merupakan sumber daya yang mempengaruhi terhadap keberhasilan dan kegagalan suatu implementasi. Sumber daya peralatan merupakan sarana yang digunakan untuk operasionalisasi implementasi suatu kebijakan yang meliputi gedung, tanah dan sarana yang semuanya akan memudahkan dalam memberikan pelayanan dalam implementasi kebijakan (Edward III, 1980:102). 


\section{Upaya Memperbaiki Pengelolaan Aset Daerah Yang Lebih Baik di Kabupaten Bolaang Mongondow}

Untuk menyelesaikan masalah dan kendala terkait pemindahtanganan dan penghapusan, maka upaya yang dilakukan oleh Pemerintah Kabupaten Bolaang Mongondow yaitu melakukan penilaian terhadap barang-barang yang rusak dan yang sudah lewat masa manfaatnya berdasarkan usulan dari tiap SKPD untuk dinilai oleh pihak yang independen dalam hal ini dilaksanakan oleh Kantor Pelayanan Kekayaan Negara dan Lelang (KPKNL) Manado. Kemudian hasil penilaian yang sudah dilakukan oleh KPKNL nantinya akan ditindaklanjuti dengan proses pemindahtanganan (lelang) atas barang-barang yang telah dinilai, selanjutnya akan diterbitkan Surat Keputusan Bupati Boalang Mongondow tentang penghapusan barang milik daerah yang telah di lelang. Selain itu, proses penilaian juga dilakukan dalam rangka pengamanan dan pemeliharaan aset.

Penilaian aset ini juga dilakukan dalam rangka mengamankan aset-aset berupa kendaraaan dinas yang masih berada ditangan pejabat-pejabat yang telah pindah tugas daerah, atau pindah SKPD maupun pejabat yang telah pensiun. Penilaian adalah sebuah penganggaran atau estimasi nilai dari suatu kepentingan atas sebuah properti/harta untuk suatu tujuan tertentu (Hidayat dan Harjanto, 2013:12). Penilaian barang daerah dilakukan oleh lembaga independen yang bersertifikat dibidang pekerjaan penilaian barang, sesuai dengan peraturan perundang-undangan dan ditunjuk oleh Kepala Daerah.

Upaya legal audit dimaksudkan untuk memenuhi proses pengamanan dan pemeliharaan aset. pemerintah daerah melalui Badan Keuangan Daerah dan SKPD sedang mengupayakan adanya sertifikat untuk pengamanan aset secara legal audit pada aset berupa tanah yang dimiliki oleh pemerintah daerah. Para pengurus barang juga sedang melakukan penarikan aset berupa kendaraan yang berada ditangan pejabat sebagai bentuk pengamanan aset secara fisik. Siregar (2004: 519) mengatakan bahwa legal audit merupakan lingkup kerja manajemen aset berupa inventarisasi status penguasaan aset, sistem dan prosedur penguasaan atau pengalihan aset, identifikasi dan mencari solusi atas permasalahan legal dan upaya untuk memecahkan berbagai permasalahan legal yang terkait dengan penguasaan atau pengalihan aset. Permasalahan legal yang sering ditemui antara lain status hak penguasaan yang lemah, aset dikuasai pihak lain, pemindahtanganan aset yang tidak termonitor dan lain-lain.

Selanjutnya upaya inventarisasi aset dilakukan melalui proses pembinaan, pengawasan dan pengendalian, pengamanan dan pemeliharaan, pemindahtanganan dan penghapusan untuk mengetahui keberadaan aset dan berguna untuk memperbaiki pencatatan aset dalam Kartu Inventaris Barang dan Neraca Daerah. Sensus barang ini baru mulai dilakukan pada saat bergantinya kepala daerah yang baru dengan tujuan untuk mengupayakan pengamanan, pemanfaatan, penilaian, pemindahtanganan dan penghapusan aset yang telah rusak atau tidak bisa digunakan/diperbaiki lagi. Inventarisasi ini dimulai dengan menelusuri aset-aset beserta bukti kepemilikan seperti aset tetap berupa tanah. Pentingnya inventarisasi aset sebagai salah satu upaya yang dilakukan pemerintah Kabupaten Bolaang Mongondow untuk menelusuri dan mengumpulkan aset-aset yang dimiliki guna memperbaiki pengelolaan aset mulai dari pencatatannya, agar data akuntansi dan fisik, sesuai serta dapat mengamankan dan memanfaaatkan aset secara optimal.

Berdasarkan Keputusan Menteri Dalam Negeri Nomor 152 Tahun 2004 Tentang Pedoman Pengelolaan Barang Daerah, menyatakan inventarisasi adalah kegiatan atau tindakan untuk melakukan perhitungan, pengurusan, penyelenggaraan, pengaturan, pencatatan data dan pelaporan barang dalam pemakaian, dari kegiatan inventarisasi disusun buku inventaris yang menunjukkan semua kekayaan daerah yang bersifat kebendaan, baik yang bergerak maupun yang tidak bergerak. Siregar (2004:518) menyatakan bahwa buku inventaris tersebut memuat data yang meliputi lokasi, jenis/merk, tipe, jumlah, ukuran, harga, tahun pembelian, asal barang, keadaan barang dan sebagainya. Agar buku inventaris dapat digunakan sesuai fungsi dan peranannya, maka pelaksanaannya harus tertib, teratur dan berkelanjutan, berdasarkan data yang benar, lengkap dan akurat sehingga mampu memberikan informasi yang tepat, berfungsi dan berperan yang sangat penting dalam rangka a) pengendalian, pemanfaatan, pengamanan dan pengawasan setiap barang; b) usaha untuk menggunakan, memanfaatkan setiap barang secara maksimal sesuai dengan tujuan dan fungsinya masing-masing; dan c) menunjang pelaksanaan tugas pemerintahan.

Upaya terakhir yaitu komitmen pimpinan yang dilakukan melalui proses pembinaan, pengawasan dan pengendalian. Setelah bergantinya kepala daerah yang baru, serta dirombaknya struktur organisasi yang ada sebelumnya, maka tindaklanjut atas kelemahan sistem pengendalian 
intern terkait pengelolaan aset daerah yang dimulai dari komitmen organisasi lewat pimpinan yang bertugas untuk mengawasi dan mengendalikan jalannya pengelolaan baik itu pengelolaan keuangan maupun pengelolaan aset daerah. Dengan adanya terobosan dari Sekertaris Daerah dan Kepala Bidang Aset Badan Keuangan Daerah yaitu dalam rangka pengawasan dan pengendalian aset yang diharapkan dapat berjalan dengan baik serta memberikan feedback bagi pengelolaan aset daerah sebagai bentuk dari tindaklanjut atas rekomendasi yang diberikan oleh BPK pada tahun 2015 dan 2016.

Menurut Rivai (2008: 45), pemimpin harus menjalin hubungan kerja yang efektif melalui kerja sama dengan orang-orang yang dipimpinnya. Semua program kerja akan terlaksana berkat bantuan orang-orang yang dipimpin, karena setiap pemimpin tidak mungkin bekerja sendiri. Menurut Gusman (2012), kesuksesan suatu organisasi tergantung pada kinerja para pegawai yang berada paling bawah dalam suatu piramida organisasi, dan para pegawai yang bekerja membutuhkan dukungan dari pimpinan. Sebagus apapun gagasan dari bawah tanpa adanya dukungan dari pemimpin maka gagasan tersebut tidak akan berjalan dengan baik. Hal ini juga berlaku untuk pengelolaan barang milik daerah. Menurut Yusuf (2010: 47), pengelolaan barang milik daerah selain membutuhkan kompetensi sumber daya manusia yang memadai, juga sangat memerlukan komitmen pimpinan untuk mendorong aparat dibawahnya agar mencapai visi dan misi yang telah ditetapkan.

\section{Penutup}

Kesimpulan dalam penelitian ini adalah: 1) pengelolaan barang milik daerah Kabupaten Bolaang Mongondow dilaksanakan berdasarkan Permendagri No. 19 Tahun 2016, namun hanya meliputi sepuluh proses yaitu perencanaan kebutuhan dan penganggaran, pengadaan, penggunaan, pemanfaatan, pengamanan dan pemeliharaan, penilaian, pemusnahan, penghapusan, pemindahtanganan, penatausahaan serta pembinaan, pengawasan dan pengendalian; 2) kendala yang ditemui dalam pengelolaan barang milik daerah yaitu rendahnya kepatuhan, belum adanya peraturan daerah tentang pengelolaan aset daerah, inventarisasi aset yang belum efektif dan optimal, kompetensi sumber daya manusia yang belum memadai, lemahnya komitmen pimpinan dan kurangnya sumber daya dalam bentuk anggaran dan fasilitas; 3) upaya yang dilakukan pemerintah daerah Kabupaten Bolaang Mongondow yaitu mengadakan penilaian aset, mengupayakan legal audit, melakukan inventarisasi aset dan perbaikan dalam komitmen pimpinan melalui pengawasan dan pengendalian.

Saran yang dapat diberikan dari penelitian ini yaitu: 1) pentingnya menetapkan regulasi dalam bentuk peraturan daerah yang merupakan turunan dari Permendagri No. 19 Tahun 2016 yang menjadi pedoman dan SOP pada pelaksanaan pengelolaan aset daerah; 2) perlunya perbaikan dalam hal kepatuhan, sikap, persepsi, dan tanggung jawab atas pentingnya aset daerah untuk semua aparatur daerah baik sebagai pengguna barang, pengurus barang maupun kepala SKPD yang bertanggung jawab terhadap penatausahaan aset daerah yang berada di lingkup SKPDnya; 3) perlu memperbaiki komitmen pimpinan agar lebih tegas dan meningkatkan pengawasan serta pengendalian melalui strategi reward dan punishment atas kinerja aparatur daerah yang bertugas mengelola, mengurus dan menggunakan aset daerah; 4) perlu adanya keterlibatan para pengurus barang dalam proses perencanaan barang milik daerah untuk mengurangi kesalahan dalam proses perencanaan sehingga pengelolaan barang milik daerah dapat terlaksana secara efektif dan efisien; 5) mengupayakan proses pengamanan aset dalam bentuk legal audit melalui proses penerbitan sertifikat sebagai bukti kepemilikan untuk aset seperti tanah yang masih bermasalah dan didukung dengan fasilitas gudang untuk mengamankan aset khususnya peralatan mesin dan kendaraan yang dimiliki tiap-tiap SKPD; 6) perlu adanya Sistem Informasi Manajemen Aset yang dikenal dengan SIMDA-BMD untuk membantu jalannya proses penatausahaan yang lebih baik dengan memberikan akses pada masing-masing SKPD untuk mengolah data asetnya menggunakan SIMDA-BMD.

\section{Daftar Pustaka}

Badan Pemeriksa Keuangan Republik Indonesia Perwakilan Sulut. 2016. Siaran Pers Laporan Hasil Pemeriksaan Laporan Keuangan Pemerintah Daerah.

Creswell, John W. 2010. Terjemahan: Research Design Pendekatan Kualitatif, Kuantitatif dan Mixed. Pustaka Pelajar. Yogyakarta.

Edward III, George C. 1980. Implementing Public Policy. Congressional Quarterly Press. Washington. Endraswara, Suwardi. 2013. Metodologi Penelitian Sastra. Yogyakarta: CAPS (Center for Academic Publishing Service).

Hidayat, Wahyu dan Budi Harjanto. 2013. Konsep Dasar Penilaian Properti, Edisi pertama, BPFE UGM, Yogyakarta. 
Hutapea, Parulian dan Nurianna Thoha. 2008. Kompetensi Plus. PT Gramedia Pustaka Utama. Jakarta. Inayah. 2010. Studi Persepsi Faktor-Faktor Yang Mempengaruhi Implementasi Kebijakan Pengelolaan Aset Daerah di Kota Tangerang. Tesis. FISIP. Universitas Indonesia.

Munaim. 2012. Kebijakan Pengelolaan Barang Milik Daerah Pada Pemerintah Provinsi Nusa Tenggara Barat. Tugas Akhir Program Magister (TAPM). Program PascaSarjana, Universitas Terbuka. UPNJJ Mataram.

Purwanto, Irwan Agus dan Dyah Ratih Sulistyastuti. 2012. Implementasi Kebijakan Publik: Konsep dan Aplikasinya di Indonesia. Gava Media. Yogyakarta.

Republik Indonesia. 2004. Keputusan Menteri Dalam Negeri Nomor 152 Tahun 2004 Tentang Pedoman Pengelolaan Barang Daerah Menteri Dalam Negeri. Jakarta.

Republik Indonesia. 2010. Peraturan Presiden Republik Indonesia Nomor 54 Tentang Pengadaan Barang/Jasa Pemerintah. Jakarta.

Republik Indonesia. 2010. Peraturan Pemerintah Nomor 71 Tahun 2010 Tentang Standar Akuntansi Pemerintahan. Jakarta.

Republik Indonesia. 2016. Peraturan Menteri Dalam Negeri Nomor 19 Tahun 2016 tentang Pedoman Teknis Pengelolaan Barang Milik Daerah. Jakarta.

Rivai, Veithzal. 2008. Manajemen Sumber Daya Manusia untuk Perusahaan. PT. Raja Grafindo Persada. Jakarta.

Simamora, Rudianto. 2012. Faktor-Faktor yang Mempengaruhi Pengelolaan Aset Pasca Pemekaran Wilayah dan Pengaruhnya Terhadap Kualitas Laporan Keuangan Pemerintah di Kabupaten Tapanuli Selatan. Jurnal Ekonomi dan Bisnis. Volume 10 Nomor 01. Halaman 47-61. Universitas Gajah Mada. Yogyakarta.

Siregar, Doli. D. 2004. Management Asset Srategi Penataan Konsep Pembangunan Berkelanjutan secara Nasional dalam Konteks Kepala Daerah sebagai CEO's pada Era Globalisasi dan Otonomi Daerah. PT Gramedia Pustaka Utama. Jakarta.

Sugiyono. 2015. Memahami Penelitian Kualitatif. Alfabeta. Bandung.

Suharto, Edi. 2012. Analisis Kebijakan Publik. Alfabeta. Bandung.

Sutaryo. 2010. Manajamen Aset Daerah. Jurnal Akuntansi FE UNS. Halaman1-9. Universitas Negeri Semarang.

Syamsuddin. 2016. Pentingnya Manajemen Aset. Universitas Islam Negeri Alauddin. Makassar.

Tjandra, Riawan, W dan Budi Harsono, Kresno. 2009. Legislatif Drafting Teori dan Teknik Pembuatan Peraturan Daerah. Universitas Atma Jaya. Yogyakarta.

Winarno, Budi. 2002. Kebijakan Publik: Teori dan Proses. Media Presindo. Yogyakarta.

Wirjosoegito, Soenobo. 2004. Proses \& Perencanaan Peraturan Perundang-Undangan. Ghalia Indonesia. Jakarta.

Yusuf, Mohammad. 2010. Langkah Pengelolaan Aset Daerah Menuju Pengelolaan Keuangan Daerah Terbaik. Salemba Empat. Jakarta. 